\title{
MAKING A REQUEST TO THE EMPEROR: RESCRIPTS IN THE ROMAN EMPIRE
}

By

\section{A.J.B. SIRKS}

1. On the Ides of March, Julius Caesar walked towards the Senate, when someone gave him a letter, disclosing the conjuration against him. But Caesar put it with the other letters he kept in his left hand, to read it later: libellumque insidiarum indicem ab obvio quodam porrectum libellis ceteris quos sinistra manu tenebat, quasi mox lecturus commiscuit (Suetonius, Vita Caesaris 82). We see that handing over a letter to a magistrate has a long tradition in Rome. I want to focus on those letters, which contained a request. It is certainly no fresh field. After Wilcken paved the way by his article in 1920, others have followed, amongst whom I mention Nörr, Honoré, Millar, Williams, Haensch, Coriat and Hauken'. Why this interest? It is because the answers to these requests, when concerning legal matters, have been considered a source of law, if they contained the formulation of a general rule. As such they ranked among the leges datae, the orationes et epistulae senatu, the edicta, the mandata, and the decreta. These are mentioned as the sources of law generated by the emperor ${ }^{2}$. They are by some scholars called ius novum, a third kind of law next to the laws originating in the state (customary law, senatus consulta, acts - the leges rogatae and the plebiscita) and in the honorary law (the edicta and the actiones): originating in the person of the emperor; but such a sharp distinction is not classical ${ }^{3}$. For example, the edicts were a source of law in

\footnotetext{
${ }^{1}$ U. Wilcken, 'Zu den Kaiserreskripten', Hermes 55 (1920), 1-42; F. Millar, The Emperor in the Roman World (London 1977, 2nd ed. 1992); W. Williams, 'The Publication of Imperial Rescripts', Zeitschrift für Papyrologie und Epigraphik 40 (1980), 283-294; D. Nörr, 'Zur Reskriptenpraxis in der hohen Prinzipatszeit', Zeitschrift der Savigny-Stiftung, Rom. Abt. 98 (1981), 1-46; J.D. Thomas, 'Subscriptions to Petitions to Officials in Roman Egypt', in: E. van 't Dack, P. van Dessel and W. van Gucht, edd., Egypt and the Hellenistic World. Proceedings of the International Colloquium, Leuven 24-26 May 1982 (Leuven 1983); R. Haensch, 'Das Statthalterarchiv', Zeitschrift der Savigny-Stiftung, Rom. Abt. 109 (1992), 209-307; A.M. Honoré, Emperors and Lawyers (Oxford 1994, 2nd., compl. rev. ed.); J.-P. Coriat, Le Prince législateur (Paris/Rome 1997); T. Hauken, Petition and Response. An Epigraphic Study of Petitions to Roman Emperors 181-249 (Bergen 1998). I was unable to consult R. Orestano, Gli editti imperiali: contributo alla teoria della loro validità ed efficacia nel diritto romano classico (1937), as mentioned in Millar, op.cit., $253 \mathrm{n}$. 3. The Codex Theodosianus in the edition of Th. Mommsen, ed., Theodosiani Libri XVI (Berlin 1904) will be cited throughout as CTh.

${ }^{2}$ See Gaius, Institutiones 1.5 .

${ }^{3}$ See A. Berger, Encyclopedic Dictionary of Roman Law (Philadelphia 1953), s.v. 'ius novum'.
} 
the Republic as well, and senatus consulta did play a part in the early Principate.

2. The emperor had the choice between various forms of legal enactments: edictum, mandatum, rescriptum, decretum ${ }^{4}$. A decretum was a verdict given in a legal procedure, held in first and only instance with the emperor in a judicial role, in a cognitio extraordinaria. He would consult his consilium, in which also jurists participated ${ }^{5}$. Millar assumes that the emperor only took on such a suit, if he wanted to do so and that litigation before another judge would have been possible ${ }^{6}$, but Kaser \& Hackl do not make this distinction?

An edictum was given by the emperor on the basis of imperium, presumably his imperium proconsulare which, so we must assume, he exercised in all the provinces, the distinction between imperial and senatorial provinces no longer being significant.

A mandatum was, basically, merely valid between the emperor and his delegates such as provincial lieutenants, but, since its contents were perpetuated, gained general validity in the sense that the provincials could refer to it. We would nowadays speak of the confidence, generated in the public. An example of this is the Gnomon Idiologou.

A rescriptum is the answer to a petition. Everybody could petition to the emperor, as to (other) magistrates. Gender did not prohibit women to address themselves directly to the emperor - perhaps this explains the number of women amongst the addressees in Justinian's Code. There was no legal right to petition; it belonged to the social sphere where everybody could write to everybody. But we see a requirement set, in order to be read and get an answer (rescript): with petitioners of lower status the petitioner had to hand over, in person, his petition, in the form of a libellus (preces, supplicatio). If it concerned a town or village, either an embassy of the town or a towns/villageman might hand over; with private persons the petitioner might be represented by a close of kin. Large cities and private petitioners of high social status could send a letter (epistula, relatio, consultatio) to the

\footnotetext{
${ }^{4}$ See Berger 1953, op.cit. (n.3), s.v. 'constitutiones principum'.

${ }^{5}$ M. Kaser, Das römische Zivilprozessrecht, 2. Aufl., neu bearbeitet von K. Hackl (München 1996), 449.

${ }^{6}$ Millar 1992, op.cit. (n.1), 94-97.

${ }^{7}$ Kaser \& Hackl 1996, op.cit. (n.5), 633.
} 
emperor and would receive an answer by letter. If the emperor did not write himself, he would authenticate the answer with a scripsi or rescripsi. Also, but exceptionally, the emperor had someone else answer petitions. The petitions by letter do not concern us further. I restrict myself to the libelli and the answers, the subscriptions (so called since they were written at the bottom of the petition). I further restrict myself to requests concerning legal questions. Requests could and would concern anything and consequently rescripts did so too. The Theodosian Code even has as rubric De diversis rescriptis (= various kinds of rescripts), and the contents show that a rescript could also, for example, include a personal favour. But how was a decision reached in legal matters, for example in cases in which a judge asked the emperor's opinion (a consultatio) or an individual asked him for legal help (a preces or supplicatio)?

3. A fine example of the procedure is found in Dig.37.14.17.pr. Ulp. 11 Iul. \& Pap. ${ }^{10}$ :

Divi fratres in haec verba rescripserunt: "Comperimus a peritioribus dubitatum aliquando, an nepos contra tabulas aviti liberti bonorum possessionem petere possit, si eum libertum pater patris, cum annorum viginti quinque esset, capitis accusasset, et Proculum, sane non levem iuris auctorem, in hac opinione fuisse, ut nepoti in huiusmodi causa non putaret dandam bonorum possessionem. Cuius sententiam nos quoque secuti sumus, cum rescriberemus ad libellum Caesidiae Longinae: sed et Volusius Maecianus amicus noster ut et iuris civilis praeter veterem et bene fundatam peritiam anxie diligens religione rescripti nostri ductus sit ut coram nobis adfirmavit non arbitratum se aliter respondere debere. Sed cum et ipso Maeciano et aliis amicis nostris iuris peritis adhibitis plenius tractaremus, magis visum est nepotem neque verbis neque sententia legis aut edicti praetoris ex persona vel nota patris sui excludi a bonis aviti liberti: plurium etiam iuris auctorum, sed et Salvi Iuliani amici nostri clarissimi viri hanc sententiam fuisse" (= The deified brothers issued the following rescript: "We have learned from those skilled in giving legal opinions that it has sometimes been doubted whether a grandson can seek bonorum possessio against the

\footnotetext{
${ }^{8}$ W. Williams, 'The Libellus Procedure and the Severan Papyri', Journal of Roman Studies 64 (1974), 86-103, contrary to the older view of Wilcken, no longer accepted; Coriat 1997, op.cit. (n.1), 389.

${ }^{9}$ Millar 1992, op.cit. (n.1), 242, Coriat 1997, op.cit. (n.1), 302-303 and 398 (Caracalla, who left the receipt and answering of libelli to his mother Julia Domna in 214-215 and 216-217).

${ }^{10}$ Other cases in Millar 1992, op.cit. (n.1), 238-239, 268-269; in general on the subject: Millar 1992, op.cit. (n.1), 240-252.
} 
testament in respect of the property of his grandfather's freedman, if the grandson's father, being twenty-five years old, had accused this freedman on a capital charge and that Proculus, clearly no light-weight legal authority, had been inclined to think that the grandson should not be granted bonorum possessio in such a case. We, too, followed his opinion when we answered the petition of Caesidia Longina. But likewise our friend Volusius Maecianus, apart from his long and well-established skill in the civil law being meticulously careful, was induced by respect for our rescript to confirm in our presence that he did not think another answer should be given. Yet when we discussed the matter more fully with the same Maecianus and other friends of us, skilled in the law, after they had been summoned, the better view appeared to be that neither in the words nor by the spirit of the law or of the praetorian edict the grandson is excluded from the inheritance of his grandfather's freedman on ground of the person of or the censorial mark against his father. Such was also the view of several legal authorities, but also of Salvius Julianus, our friend and most honourable man.")".

It concerns a rescript of Marcus Aurelius and Lucius Verus (joint emperors in A.D. 160-169), apparently in the form of a letter. They refer to a former rescript on the same question, which had been published in answer to a libellus and therefore had probably been much shorter that this rescript. At that time the emperors followed Proculus' opinion. Since this jurist lived in the first century, they - or their staff - must have consulted his writings. Furthermore, the rescript or a copy of it must have been in the imperial archives and it must have been routine to check previous rescripts on similar cases $^{12}$. The decision was that the grandson was not allowed bonorum possessio.

After the dossier had been presented before the emperors ${ }^{13}$, they did not simply adopt the cited opinion of Proculus, like they had done in the first case, but they consulted their counsellor, Volusius Maecianus. He did not see a reason to answer (respondere) otherwise. Volusius Maecianus, who died in

\footnotetext{
${ }^{11}$ Translation after A. Watson, The Digest of Justinian (Philadelphia, PA, 1999). Honoré 1994, op.cit. (n.1), 18-19 mentions this text also, without, however, drawing any conclusions.

${ }^{12}$ That a former rescript was cited, means that an archive was kept of the petitions or copies of them; according to Coriat 1997 , op.cit. (n.1), 254, this was the responsability of the scrinium a studiis. It also follows that the archive was used to check new decisions on consistency with previous decisions. Coriat 1997, op.cit. (n.1), 633: similar citation of earlier rescript.

${ }^{13}$ Coriat 1997, op.cit. (n.1), 273-274, prepared by the chanceries.
} 
175, was a libellis et censibus under Hadrian and Pius ${ }^{14}$, Prefect of Egypt about 160, after having been Prefect of the Annona, and in an inscription he is called iurisconsultus (the first jurist we know this of), which might refer to the ius respondendi $i^{15}$.

The emperors asked for advice again, this time not only from Volusius Maecianus, but also from others, likewise jurists, and this time they reached a different conclusion. There was nothing to deny the grandson bonorum possessio, so apparently decided the majority of the legal authorities, including Salvius Julianus. It is not clear whether these men were jurists who were present at the consultation or jurists whose writings were consulted. I would like to assume the latter, since the reference is made after the decision has been mentioned, as if to confirm it by citing literature.

The procedure implies that normally the case would be finished without consilium, merely by following the advice of the staff and writing scripsi or rescripsi. Coriat thinks that the heads of the scrinia participated in the discussion ${ }^{16}$. In my view this is not likely: it would diminish the significance of the consilium, which we see here, as Coriat observes, functioning in a legislative way ${ }^{17}$.

In this case an answer was drawn up in the form of a letter. With a libellus the answer would be written at the bottom, in a more lapidaric style. The emperor would sign, in order to authenticate the answer.

In the next section of the Digest another question is discussed, apparently by the same emperors and perhaps on the same occasion: here the opinion of Proculus was set against that of Julian, with whom the emperors concurred. Apparently this case was decided on the writings alone.

4. How did the petitioner hear of the outcome? According to Wilcken, until Hadrian the petition was returned with the subscription. From the reign of that emperor onwards the libellus, with the subscription, was hung out in public for some time, so that the petitioner might read it and make his own

\footnotetext{
${ }^{14}$ To all probability Maecianus was no longer a libellis et censibus at the time of this case.

${ }^{15}$ C. Ebner, s.v. 'Volusius', Der kleine Pauly 5 (Munich 1975), 1332; W. Kunkel, Herkunft und Stellung der römischen Juristen (Graz 1967), 174ff.; A.M. Honoré, Tijdschrift voor Rechtsgeschiedenis 32 (1964), 39.

${ }^{16}$ Coriat 1997, op.cit. (n.1), 274 ff.

${ }^{17}$ Coriat 1997, op.cit. (n.1), 200 ff.
} 
copy. The notation $P P$, for propositus or proposita, often seen in rescripts, would indicate such a procedure ${ }^{18}$.

Wilcken's article has remained fundamental, but in the course of time adjustments have been made. To give one example: According to Nörr and Williams, the method of publication was different from the early second century onwards ${ }^{19}$. The original libellus with subscription remained in the imperial archives and the petitioner got an attested copy to take it home. One

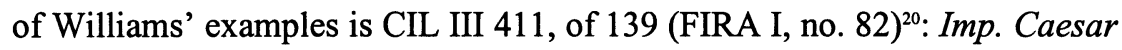
T. Aelius Hadrianus Antoninus Augustus Pius/Sextilio Acutiano. Sententiam divi patri mei/si quid pro sententia dixit describere tibi permitto./ Rescripsi Recogn. Undevicensimus. Act. VI. Idus April. Romae Caes./ Antonino II et Praesente II cos. (= The emperor Caesar T. Aelius Hadrianus Antoninus Augustus Pius to Sextilius Acutianus. I allow you to copy the verdict of my deified father, if he did say something as verdict. I replied. I checked [it]. The nineteenth [book]. Done on the 6th day before the Idus of April, in Rome, in the consulate of Caesar Antoninus [for the 2nd time] and Praesens [for the 2nd time] ).

The "I checked (it)" would be the mark of the issuing official, "nineteenth" would be the 'docket', an indication of the sheet on which petition and subscript were written within the volumen of documents ${ }^{21}$. It is clear that there was an archive, but such was already indicated by Dig.37.14.17.pr. According to Hauken, however, it concerned, in this case, the commentarii, access to which normally was closed to the public ${ }^{22}$. Likewise the rescript to the Scaptopareni, of $238 \mathrm{AD}$, testifies to the existence of an archive and the habit to produce copies from $\mathrm{it}^{23}$. There was a liber libellorum rescriptorum et propositorum. If the originals were kept, the book must have consisted of individual libelli, glued together: a synkollesis ${ }^{24}$. If the original was returned to petitioners, it would consist of copies and then

\footnotetext{
${ }^{18}$ Wilcken 1920, op.cit. (n.1), 9 ff.; W. Williams, 'The Publication of Imperial Subscripts', Zeitschrift für Papyrologie und Epigraphik 40 (1980), 283-294.

${ }^{19}$ Nörr 1981, op.cit. (n.1); W. Williams, 'Epigraphical Texts of Imperial Subscripts: A Survey', Zeitschrift für Papyrologie und Epigraphik 66 (1986), 183-184, 187.

${ }^{20}$ Williams 1980, op.cit. (n.18), 291; Nörr 1981, op.cit. (n.1), 25-26: "dürfte ... aus dem Archiv stammen."; Williams 1980, op.cit. (n.19), 182-187.

${ }^{21}$ Williams 1986, op.cit. (n.19), 183.

${ }^{22}$ Hauken 1998, op.cit. (n.1), 103-104.

${ }^{23}$ IG Bulg. IV, 2236; FIRA (= Fontes Iuris Romani Antejustiniani ), Pars Prima (Florence 1968), 507. Nörr 1981, op.cit. (n.1), 26-27 again in favour of an archival origin.

${ }^{24}$ Williams 1986, op.cit. (n.19), 183-184; 202-203.
} 
no synkollesis is to be assumed. In these cases we must assume that the petitioners wanted a certified copy.

Haensch has studied the methods of the archive of the Prefect of Egypt. Originally this administrator answered every petition with a subscription and the mark: apodos, give, namely the subscribed petition itself, to the petitioner. Perhaps a copy was supplied by the petitioner for the archive. Whatever the system followed, we see, in any case from 207 onwards, a new method. The petitions were subscribed and then glued together in massive rolls. Every column, which had been created in this way, got a number and petitions were cited with this number. If necessary the rolls themselves got a number too. Petitioners could note roll- and petitionnumber whenever they could inspect the created rolls (synkolleseis) and afterwards they could provide themselves with a certified copy of the texts. The numbers now began to form part of the copied subscriptio ${ }^{25}$. Similar procedures are found with the governors of Iudaea (in 150), Syria (in 245), and Arabia (perhaps already in 131) ${ }^{26}$. Lower administrators in Egypt often stuck to the older way with an apodos. With the imperial chancery we see the synkollesis-method, already since the days of Antoninus Pius, vide the rescript to Sextilius Acutianus.

Whether this method would solve the problem of the volume is to be doubted. But it certainly made the mass of rescripts accessible. More accessible? We do not know how they had been archived before. One wonders, if any indexes were made. It seems likely: how else would one find similar cases of the past? Rerunning all books or rolls every time would have been too time-consuming, even in a society in which labour was cheap.

It is anyway clear that this way of treating the petitions and rescripts did not make their contents available to the public at large. Only those petitioners who submitted their papers simultaneously, would learn of their own and some other rescripts. Only those who had time and money to spend all day and copy, could hope to gather some information. One would have to ask permission first. And then to think, that the legally relevant rescripts may have formed but a small part of all rescripts! The collection known as Apokrimata gives us a valuable clue in this respect. If there were no indexes, the archives must have been inaccessible to the general public.

\footnotetext{
${ }^{25}$ R. Haensch, 'Die Bearbeitungsweise von Petitionen in der Provinz Aegyptus', Zeitschrift für Papyrologie und Epigraphik 100 (1994), 505.

${ }^{26}$ Haensch 1994, op.cit. (n.25), 511.
} 
Jurists who had access to the archives collected and cited rescripts in their writings, which they had found there, working in the archives, or they quoted from memory, relying on their experience in the imperial consilium or scrinia. Although they sometimes cited them literally, they frequently paraphrased them, which could result in altering the original sense. Some collections of the texts themselves existed already in the early third century, for example Papirius Iustus' Liber Constitutionum. The Codices Gregoriani and Hermogeniani were the most significant ones ${ }^{27}$. In these volumes the rescripts were arranged according to subject-matter, undoubtedly a step forward. Perhaps their makers relied on existing indexes of the chanceries. In a petition, published later than $324 \mathrm{AD}$, a law (nomos) is cited which could be a rescript of Diocletian and Maximinus of 293 (CJ 2.19.7) ${ }^{28}$. The petitioner had possibly read this law in the Gregorian Code, but unfortunately no indications are given. Yet the case clearly indicates that such a Code would have an impact on litigation.

5. What was the function of the rescript system? Wenger saw rescripts, because of the authentic interpretation, as new "Rechtsentstehungsquellen"29; Honsell, Mayer-Maly and Selb as replies to a legal question ("Rechtsfrage") with authority ("autoritative Rechtsbelehrung"), similar to the opinions of jurists having the ius respondi, but anyway binding. ${ }^{30}$ Honore distinguishes three functions. It was a social service since it provided the citizen with a free legal advice service; it provided an authoritative ruling on the law; it promoted the unity of the law and helped adapt it to the needs of society. ${ }^{31}$ Coriat sees the rescript as an "instrument de centralisation institutionelle dans le droit procédurale", and this "technique transforme le rescrit de simple responsum en un acte de nature juridictionelle, qui acquiert une valeur quasi décrétale: au titre de décret conditionnel, les dispositions qu'il préscrit s'imposent au juge, sous réserve du controle de la véracité des faits

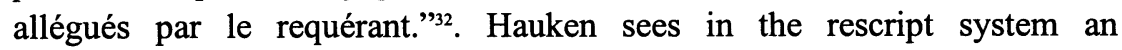
implementation by the emperors of their objectives, which were made

\footnotetext{
${ }^{27}$ Nörr 1981, op.cit. (n.1), 34, thinks it possible that for the Codex Gregorianus various collections were used.

${ }^{28}$ See A.J.B. Sirks, 'Aurelius Neilammon alias Hiërax and Caecilius [Cons]ultius, Prefect of Egypt, in a Case of Extortion (P.Strasb. VI 560)', Tyche 10 (1995), $179 \mathrm{ff}$.

${ }^{29}$ L. Wenger, Die Quellen des Römischen Rechts (Wien 1948), 429.

${ }^{30}$ H. Honsell, Th. Mayer-Maly and W. Selb, Römisches Recht (Berlin 1987), 19-20.

${ }^{31}$ Honoré 1994, op.cit. (n.1), 33, 38 and 41 respectively.

${ }^{32}$ Coriat 1997, op.cit. (n.1), $338 \mathrm{f}$.
} 
explicit through directly responding to the approaches of their subjects. They legislated by reaction, so to speak ${ }^{33}$. What to make of this?

Firstly the requirement to present the request in person or by selected representatives. Why this requirement? The question is, surprisingly, not posed in the literature. A clarifying example. We saw that Julius Caesar was approached in the morning with requests, while he was walking towards the Senate's meeting place. This approach took the shape of a morning greeting a Roman grand seigneur was used to. People used the opportunity of the morning greeting to ask for favours or for help, or advice, including legal advice. For that reason law formed part of the education of the higher social circle. It seems to me that if the rescript-system developed out of requests made during the salutatio matutina, the morning greeting, of clientes towards their patrons, the requirement to present requests in person at morning greetings of emperors must be a survival of former salutatio habits. Similarities point in this direction. Social convention prescribed important persons to receive anyone, certainly dependent persons who paid their respect ${ }^{34}$. Rescripts were, then, the continuation of, or successor to the advisory duty of the Roman patron towards his clientes. The emperor was, then, in a manner of speaking, the patron of all. When the mass of libelli made the scrinium a libellis and a rescript-procedure necessary, this, as the basis, would have been kept. Changing it into a rational system with letters sent, would have required an "Umdenken" of society by the Romans, which was not to be expected from them. Persons of high social standing of course did not have to pay respects in this way, and they could send letters. Correspondingly the emperor could not refuse to consider a request.

Another argument to see the rescript system in this light is the difficulty to put it in a legal frame. As the cited definitions show, there is no strict legal effect to rescripts: their effect is said to be based on the authority of the emperor. Coriat's quasi-decrete streches the limits too far, although the "quasi" suffices for my purpose. Its effect was unlike the consequence of a decrete, it did not impose dispositions on the judge, who remained free to take on the case or not. He should merely consider it seriously.

That the replies could be used to implement political aims, as Hauken underlines, is certainly true, but I think it goes too far to see the rescript

\footnotetext{
${ }^{33}$ Hauken 1998, op.cit. (n.1), 298.

${ }^{34}$ For the salutatio of the emperor, see R.J.A. Talbert, The Senate of Imperial Rome, Princeton 1984, 68-70.For the Romans in general, see Groß, s.v. 'salutatio', Der kleine Pauly 4 (Munich 1975), 15241525.
} 
system as the principal carrier of this objective. It depends on the area of law, and in private law changes were usually gradual and by way of adaptation. But the greatest obstacle to such an interpretation is the limited publication of rescripts, which would reduce any political effect. If any active reform were necessary in some field or another an edict or an oratio in the senate would suffice. Such devices were actually used; one may think of the oration of Septimius Severus on the prohibited donation between husband and wife, or the one prohibiting tutors and wards to alienate land of their pupils without any consent of the governor. ${ }^{35}$ In other areas explicit legislation was not unusual either. To give a few examples: one could think of Diocletian's Price Edict or of Constantine's reform of the transfer of real estate (Fragmenta Vaticana 35).

In short: I would like to consider the rescript system as an elaborated form of the salutatio cum request, to the emperor. Honorés "free legal advice service" sounds too modern and leaves aside that its availability was quite limited, but I think we should take this interpretation as a little joke, with the serious undertone that it was, if available, an inexpensive way - and that it was indeed.

6. The rescript is, then, an advice to a client. Why then the idea of authority? Was the advice of the emperor basically different from that of a powerful Roman politician during the Republic? Wouldn't a judge not have been equally impressed by that as well? Does the Empire have an impact here?

The position of the emperor did indeed differ from that of any Republican politician in that he united in his person various Republican functions or powers: the imperium proconsulare, the tribunicia potestas, the pontificate and intermittently functions like the consulate. These could influence the effect of his written replies.

We must remember that petitions could and did deal with all kinds of things; we shall restrict ourselves here to those dealing with legal problems. A judge could ask for an advice during a trial (a consultatio); a private person for an explanation or interpretation of the law. We assume, and with good reason, that the emperor's opinion would be followed. Was this

${ }^{35}$ Dig. 24.1.3.pr. Ulp. 32 ad Sabinum; Dig. 27.1.9.pr. \& 1 Ulp. 35 ad edictum. 
because of his constitutional or social preponderance, ${ }^{36}$ or because he appointed the provincial governors who would judge, whether in first instance or in appeal (the same applying for higher imperial functionaries)? I shall certainly not rule out these possibilities, since they will have been present anyway. Yet that still does not make the opinions expressed to be considered, by the jurists, as legally binding rules (as follows from their being cited so). In line with the edicts I suggest that whenever the emperor replied to a petition and formulated an interpretation of the civil law, it was, or could well be considered a responsum by the pontifex maximus. By that it would gain authority. The emperors always wore this title and this priest had the authority to issue authoritative interpretations. ${ }^{37}$ After the second century this may have become a silent assumption or perhaps even customary law. So here empire did have an impact. Although the rescript system continued and florished at all levels of society ${ }^{38}$, the rescripts of the emperors did have the edge.

Did the rescript system provide a free legal advice system? As I indicated, I think that even Honoré would not take that too literally. It was clear that physical access to the emperor was only open to those who were living in his neighbourhood or who had at their disposal close relatives or townsmen, who were serving the emperor at close quarters. I leave aside persons of high social standing, who could always write a letter to the emperor: they were not in need of free legal advice. Here I think the impact of the empire was insignificant. For many people it will have been more useful to rely on near-by patrons.

Did the system promote unity of law and help to adapt it to the needs of society? What may be understood by this? Unity is possible when there is divergence, and in the empire this can only mean divergence between parts of the empire, lying far away from each other (parts close to each other will have known about each other's legal developments). Here the emperor could bring all back on the tracks. But were rescripts useful or even necessary in this respect? The answer should be: no. We saw that their publication did not bring the imperial decisions under the eyes of all; it was not even meant to

\footnotetext{
${ }^{36}$ Coriat 1997, op.cit. (n.1), 339: "La procédure dite par rescrit, en effet, a pour résultat logique que la décision impériale, de par l'autorité de laquelle émane, limite le pouvoir de décision du juge du fond par la surveillace quelle instaure sur le procès dont celui-ci connait."

37 Szemler, s.v. 'pontifex', in Pauly - Wissowa, Realenzyklopädie der classischen Altertumswissenschaft, S XV (Munich 1978), 362.

${ }^{38}$ See Hauken 1998, op.cit. (n. 1), 169-256 for an edition of epigraphically transmitted rescripts of lower officials.
} 
do so. Consultation of the imperial archives required a permission ${ }^{39}$. So for the average citizen they remained unknown, and could not provide any guidance. Only when people who had access to the archives published the decisions, they could become sufficiently widely known to cause a harmonisation of the law. But that might happen decades, or even centuries, after the relevant decision. If the emperors really wanted to impose a unity of law with regard to a particular legal point, they should - and did - promulgate an edict, since edicts were widely publicised and the decision would be known within a fairly short time within the entire empire. The binding force was also clear: edicts did have legal force.

7. We also have to keep in mind that the tradition of texts may distort our view. We possess, basically, two collections of legal rescripts from the second and third centuries A.D. We don't have the faintest idea what proportion they formed compared to the total of rescripts issued by the emperors, nor to the mass of rescripts issued by subordinate administrators like we do not know much of imperial and prefectural edicts either. The same applies to the fourth century, but hardly any rescript from that age survives. The Theodosian Code simply did not include them. One can only guess that their number cannot have been smaller than before, and that imperial rescripts did not lack general validity. Much more is known about imperial edicts and edictal letters from this age.

But from the stress laid here on the edicts and edictal letters (see CTh 1.1.5 and 6), I think we may gather that these, with their usual promulgation by way of edicts, were considered to have more impact on the population, and that the emperors indeed considered the impact of rescripts insufficient, as it was. I think the emperor proclaimed an edict, with the accompanying publication, every time he found that a rescript led to a general rule, which necessarily should be followed by everyone.

In the Novellae Valentiniani 21.1 and 2 we see how the procedure was in 446. In Nov.Val. 21.1 there is question of a couple, Leontius and Iucunda, who were childless, who in one document instituted each other as heir as if they had the ius liberorum. They applied for the ius liberorum. Apparently in the meantime Iucunda had died. The emperor grants the request and subsequently orders the Praetorian Prefect to issue edicts, so that all may know that such testaments are granted upon petition. In Nov. Val. 21.2 the case is, that a lady Micce drew up a holographic testament, that is, without

${ }^{39}$ See CIL III 411 of $139 \mathrm{AD}$, cited above. 
witnesses. The heiress, however, refrained from taking anything from the inheritance until the emperor would have approved of the will. This the emperor does; the will is validated and the heiress can take possession. "Ne tamen huius statuti salubritatem generi negemus humano, mansura iugiter lege decernimus ..." (= Nevertheless, in order that we may not deny the salutary assistance of this statute to the human race, by a law which shall remain continuously valid we decree ...). In this case also the Praetorian Prefect has to post everywhere edicts (Nov.Val. 21.2.1). Particularly the last case shows that the petitioner receives an answer which would normally have settled the case. Perhaps in the second century a jurist might have concluded from it that apparently a new rule was being instituted. Yet it also could have been an exception. We do not know whether there were cases in which a second-century jurist indeed drew more conclusions from a rescript than was warranted for. They would have been legalised anyway by the acceptance as canonical of the writing in which it was published. But in the fourth century this concern was certainly present with the emperors. CTh 1.2.11 of 398 , states that a rescript given in reply to a consultatio by a judge, may only be used for that particular trial and not in another. Nota bene: only this kind of rescript! Other rescripts could apparently be used in a more general way, and there is no reason to think that their incidence diminished in the fourth century. Only in A.D. 426, in the West, general validity (of a rescript and other texts) was no longer assumed unless certain conditions were fulfilled.

In that time the concept of general validity attracted much attention. Rescripts may have caused this by being often too diffuse, and the repetition in an edict would make the point clear. That does not mean that rescripts - as Honoré assumes - after A.D. 398 never recovered the general force they had had before Diocletian ${ }^{40}$. They still had that potential, or otherwise the concept of general validity would not have been defined, in the West in A.D. 426 , as restricted to imperial texts with either the word edictum (an edict or an edictal letter) or the explicit intention of general validity. Likewise, in A.D. 429 and 435 it was prescribed that the Theodosian Code would contain only edictal or general constitutions: that is, texts in which either the word edictum or the word generalis had been inserted, or a general application mentioned. These were not concepts invented in A.D. 426 or 429 and then retroprojected to the fourth century. In various laws of the latter period explicit references of this kind are to be found already. The earliest text with

\footnotetext{
${ }^{40}$ Honoré 1994, op.cit. (n.1), 211.
} 
such a formal reference is CTh 11.30.3, of A.D. 315, in which Constantine says: "iam generaliter constitutum est". Another text, of A.D. 321, CTh 16.8.3, has: "cunctis ordinibus generali lege concedimus". CTh 14.3.11 of A.D. 365 or 364 (Rome) has: "hac sanctione generaliter edicimus"; CTh 6.31 .1 of 365 (W): "per omnes provincias edictum generale misimus"; CTh 4.17.1 of 374 (W): "statutis generalibus iusseramus"; CTh 2.2.1 of A.D. 376 (W): "promiscua generalitate decernimus"; and there are more examples of generaliter, generalitas or lex generalis (12) from the period up to A.D. 390 . Apparently already in Constantine's time the concept was known and applied. Precisely such texts were saved by the Theodosian compilers, who relied on the constitutions of 429 and 435 (CTh 1.1.4 and 5), which in their turn were based - as we may assume $\mathrm{e}^{41}$ - on the definitions of the Lex Citandi. Similarly those, which did not contain such references, but merely had in the pro- or epilogue (always deleted by the compilers) the order to be ordered valid for all people, would have been saved for posterity.

Yet we do not find any rescripts in the Theodosian Code. If these would have been considered as containing a general rule, they, as constitutiones generales, should have been included. The emperors could have made them into such rules by inserting into the rescript itself a similar reference to general application as they did in the letters cited above. Apparently, however, they did not. It is unlikely that rescripts were considered generally applicable constitutions in the third century A.D. and no longer so in the fourth century, or else the restriction of CTh 1.2.11 of 398 would have made no sense. Since they were not deliberately left out of the Theodosian Code, they must have been reduced to singular applications by another device. This device was, as Nov.Val. 21.2 and 3 demonstrate, that the emperors would enact edicts or edictal letters, as often as they found out that rescripts would imply or amount to general rules.

This habit may have started already under the Tetrarchs. According to Millar we see an upsurge of edicts in inscriptions in this period ${ }^{42}$. Was this due to a change in policy, through which the coordinating role of the

\footnotetext{
${ }^{41}$ Theoretically there is no absolute connection between the definitions of $\mathrm{CJ} 1.14 .2$ and 3 and the prescriptions of CTh 1.1.5 and 6. Yet it is very unlikely that they did not exist. First, since they were included in Justinian's Code, they must have been in Theodosius' also. Then, although Western, it is, in view of the Eastroman influence at that time in the Western court, hard to imagine that it would be entirely contrary to Eastern ideas. Thirdly, in Eastern law we equally see the same references to generality: CTh 5.12 .2 of 415 (East) has generali sanctione mandemus, CTh 6.12 .1 of 415 (East) generaliter iuberemus, CTh 10.10 .12 of 380 (East) in generali iubemus.

${ }_{42}$ Millar 1992, op.cit. (n.1), 257-258.
} 
emperors began to be more heavily accentuated? Perhaps, but a preference for edicts would have had its effects on the rescript praxis. Rescripts would not have been regarded, then, as suited to introduce changes in legal opinion. Whatever the cause of the change may have been, it is perhaps no coincidence that the Codices Gregorianus and Hermogenianus date from A.D. 290 and 295. They may have closed the period of rescripts of varying purport by the edition of rescripts containing truly general rules; after the publication of those codices a rescript might still contain a general rule, but in that case an edict or edictal letter would accompany it and be - being known to all inhabitants - the primary source of law. If this presupposition were true, there might even be some ground to presume that these Codes were of some official nature.

\section{Summary}

The rescript system is a development of the existing habit at Rome to present requests to patrons by way of a libellus. The expansion of Rome to an Empire with an emperor did have an impact on this system. Firstly the emperor did no longer rank amongst other patrons-senators, but, as princeps senatus and pater patriae, ranked above all others and could be considered the patron of all in the Empire. Then, in the case of legal questions, his interpretation gained, as a result of his pontifical auctoritas, binding force. On the other hand, the effect of this binding force was limited as long as rescripts had not been communicated at large, for example through a collection of rescripts. In the long run this must have posed a problem as regards general validity of rescripts problematic, since conditions were set which basically excluded rescripts from being cited as general rules. Since publication at large was implied by the parallel issuing of an edictal letter or edictum, it seems that this was a reason to adapt the rescript system.

Frankfurt am Main, December 2000. 